\title{
Transcultural Experience and Multiple Biographies as a Research Topic
}

\begin{abstract}
Transculturality refers to the traditional understanding of culture as selfcontained, concentrated around its own center and producing clear borders. "Trans" signifies the act of crossing; it signifies overcoming such borders. It looks at phenomena, people and notions that are not limited to one communicational environment but are represented in multiple locations, or contexts. Or ratherthey cannot be fully ascribed to one "culture" because they exhibit traits of both (or more) cultures. Culture studies often also describe people with "trans" life stories; it is not a matter of simple crossing of borders, living a bit in one environment and a bit in another. The point is that their sense of belonging is of a mixed, ambiguous character, and their identity is blurred. It is a question of practices that they draw from two or more sources, creating a peculiar amalgam characteristic of living "in between." Transculturality, just like multiple biographies, means both partial belonging and dual belonging, which is very well illustrated by the case studies presented in the volume: they have, in a way, varied roots, which means they bear unique, hybrid fruit.
\end{abstract}

Keywords: transculturality; biography; social identity; border

This is an Open Access article distributed under the terms of the Creative Commons Attribution 3.0 PL License (creativecommons.org/licenses/by/3.0/pl/), which permits redistribution, commercial and non-commercial, provided that the article is properly cited. (C) The Author(s), 2014

Publisher: Institute of Slavic Studies, Polish Academy of Sciences

Editor in chief: Jolanta Sujecka

Conception and academic editing of this issue: Maciej Falski 
$\bar{A} \mathrm{~s}$ we close the third issue of the annual Colloquia Humanistica Ain 2013, we are already viewing postmodern challenges and obsessions with some objectivity ${ }^{1}$. Claims that were considered a bold break with the dominant, limiting and totalizing discourse of national identity often turned out to have equally uncompromisingly forced communities into an oppressive excluding identity, just that it was based on another category - regional, ethnic or "cultural." The difference was that-unlike in modernism's national projects-forgotten, dominated or repressed identities were positively approached: Breton or Basque in France, Silesian or Kashubian in Poland, Kven in Norway, and so on. Sometimes regional identifications were preferred to national ones, as the Istrian in Croatia and Padanian in Italy. Yet the imperative was still to maintain, defend and cultivate excluding identities: fighting for the right to teach in one's language, the right to have cultural institutions and media, etc. Autonomy, founded on a sense of difference that encompassed the entire personality, and on the collective level the entire culture, became an imperative. The slogan of postmodernism - "be different!" - turned out to be as totalizing as the earlier practices of national homogenization.

One must, of course, value the contribution of scholars of the last three decades to the development of the study of cultural communities, especially in terms of ethnicity. Today the idea of a nation as an imagined community, founded mainly on the members' belief that they share the same values and symbolic code, is obvious, but it has not always been so. Many prejudices had to be overcome to discard - at least in the academic world - the ideas of the primordial character of nations, innate cultural characteristics, or unchanging traditions and identities. Modernism created sharp, clear-cut national boundaries, presenting them as eternal, unchanging through the years, and independent of contexts. No movement of individuals between national cultures was possible, and if it happened, the person changing his national culture could be considered a "traitor," at best an emigrant in danger of being uprooted. Fluid, multiethnic areas and border-territories were almost entirely removed from the European mental map after 1945, or at least, so it was claimed. The awareness that it is possible for culturally "impure" areas to exist had been lost, or at any rate, such areas were seen as a threat to the supposed cultural purity of a nation.

However, beginning in the 1970s, there were more and more studies and papers devoted to repressed identities-peoples that disappeared from the European space or the ones that were being marginalized. The memory of areas of cultural osmosis, ambiguous places, which could not be

I want to thank Ms. Aleksandra Michalska for the English translation of the paper. 
incorporated into either country without the use of brute force, was being restored. It is memory, the desire to preserve the history of the areas, at least in literature or ethnographic description that was an important stimulus for the next stage in the reflection on culture - the studies of identity that is mixed, ambiguous, different from the dominant excluding narration. The problem of the borderland as a cultural entity that is unique, different in its nature from the central regions, was taken up by the humanities. The influence of anthropology on social sciences and humanities increased, making them study everyday life that which is common and small, far removed from the holiday-time virtues of the elites. It is in those places that the possibility of the mingling of cultures, of exchange and coexistence, unattainable in the sphere of official communication, has remained. While the elites cannot understand each other and reach out for the language of confrontation based on firm divisions and the created tradition that excludes "foreign" influence, on the micro level people are still able to engage in dialogue and exchange. One of postmodernism's main slogans - bringing an end to the division into the "high" and the "low," the top and the bottom of the hierarchy of social practices - opened the intellectual horizon onto imagining communities other than (supposedly) homogenous aggregates reduced to the ideal of purity. The image of a nation was taking shape among the elites and was produced and sustained in places where high culture was manifesting itself: in school, at a school ceremony, at a parade, on the occasion of a national holiday, though, undoubtedly, popular culture played an increasingly significant role in promoting national stereotypes ${ }^{2}$. But everyday life, described by ethnographers and unveiled by scholars of microhistory, revealed a world different from the imagined purity of cultures thought to have existed since the dawn of time. The change of national cultural domination over an area was often unnoticeable, gradual; ethnic groups coexisted, sharing the space, and often certain practices, which cemented their everyday culture despite their belonging to different countries.

From the perspective of the early 21 st century, the joining of identity and territory can be regarded as one of the most dangerous social notions. It was precisely this connection that lay at the base of the policy of "cleansing the space," that is, the obsession of creating a national territory free of foreign influence. What followed was both the physical getting rid of populations considered "foreign" and the removal of signs of the cultural presence of

2 I am referring to the popular culture from before the era of mass media; scholars researching everyday life and non-elite phenomena have proved that contemporary popular culture plays a significant role in the process of national homogenization and popularization of unambiguous symbols of identity (see Anderson 1997; Edensor 2004). 
“others." Alexandra Laignel Lavastine (2010) wrote poignantly about the process in the case of Romania during the interwar period. The obsession with "Romanianness" fueled the actions of the elites and set the horizon for imagined and legislative practices, leaving a narrow margin for other points of view. In practice, it meant the marginalization and physical danger of the Magyar population, as well as a growing animosity and enmity toward Jews. In the modernistic view, Romanianness, defined rather than "discovered," could not be reconciled with numerous cultures or rather identities on the territory considered to be Romanian.

Two communities whose paradigms did not fit the modernistic vision outlined here were Jews and Romani. In both cases, so different of course, we are dealing with non-territorial communities; they are nations without states, which inhabit a considerable part of pre-modernist Europe. Granting Jews civil rights in the 19th and 20th centuries did not mean the end of discrimination; the presence and visibility of the group in the public sphere intensified the negative response of the majorities, and fabricated slander, but also pseudo-scientific journalism, led to discrimination (as in Poland during the interwar period, in Romania and other countries) and finally, to the Shoah. As they did not create "their" territory, Jews did not gain the right to existence in a world of clear-cut borders and excluding identities. After 1945 Poles eagerly took advantage of the opportunity of also a symbolic eradication of the centuries-long Jewish presence by eliminating Judaic historical sights and destroying cemeteries. The history of the prewar Jewish district in Warsaw came to be illustrative. Nothing remained of it after the ghetto had been burned down in 1943; nearly nothing has been rebuilt, and the only surviving synagogue was converted to a Roman Catholic church (Chomątkowska 2012). The actions of the Serbian authorities in the Republika Srpska, one of the two autonomous parts of Bosnia and Herzegovina, serve as another example. Since 1995 a process of Serbianisation and removal of all signs of Ottoman and Bosnian culture is being carried out in its territory. It is to be expected that at some point the semiosphere of this part of Bosnia will be "purely Serbian." So, the symbolic dimension clearly demonstrates in this case that what are at stake are political issues (Falski 2010). The Romani case is also connected with the matter of non-territoriality: the nomadic way of life was so different from what most Europeans were used to, that nearly everywhere they were afflicted by discriminatory rulings, and in the end, became the victim of a planned genocide during the Second World War (Kapralski 2012).

I do not wish to idealize, in this way, past epochs and the supposed paradise of coexistence that had been lost. I believe, however, that socially impermeable divisions into estates were replaced by modernistic borders 
of ethnic cultures which built equally sharp divisions. Yet we are dealing here with a certain cultural and political ideal that definitely did not reflect the social reality of not just borderlands, but probably of anywhere in Europe. Ethnologists, i.e. experts on the topic of culture, wondered at one point, how to reach the "authentic" layers - how to determine what was "purely French" or "purely Croatian." Serious research showed, however, that the supposed purity was always a cultural creation. "Sweet France," rural France, is a rather new creation, and contemporary scholars described the process of transforming peasants into Frenchmen or persuading Czechs that they are Czechs. And Croatian ethnologists gave up the idea of describing what was "purely" Croatian under the layers of a multitude of cultural influences as early as in the 1930s (Thiesse 1999; Macura 1995; Weber 1976; Gavazzi 1928). Even in the pantheon of heroes one could find many people that do not fit the ideal of national purity: Napoleon - a Corsican or a Frenchman?; Adam Mickiewicz - a Pole, a Belarusian, or a Lithuanian?; Catherine II - a Russian or a German?; and Nicolaus Copernicus?... The examples are endless. Posing such questions, however, is evidence of precisely the sharp cultural borders, marked out by national identities. In the feudal world, it made little sense to ask about someone's ethnicity because aristocrats formed a network of connections which were based on family ties and community of interests, while for the peasant it was not important who ruled over him, as exploitation was usually the same. The sense of national identity had the biggest role to play in the creation of the vision of homophonic and uniform cultures, separable on the basis of the principle of excluded middle: if someone is a Pole, he cannot be a German; belonging to culture A is determined by a list of characteristics absent from culture B, and so on. Exclusivism set the tone for modernistic ideas of social order and, by extension, political order. That is why poststructuralists and postmodernists aimed the sting of their statements mainly against the pretensions of nationalisms. The political expression of the call for difference and (self) differentiation were the regional movements, which, since the 1980s, have had increasingly greater say in Western Europe and then in the European Union. Respect for the relativism of cultures and the attempt to erase national exclusivism determined the standards of studying societies as well as the standards of domestic and foreign policy of European states (Kwaśniewski 1993; Dąbrowska-Partyka 2008).

But it is not only nationalism that is responsible for creating sharp borders on the map of cultural notions. In recent decades, the tone for debates on identity and society has been set by scholars and thinkers from Western Europe and North America, who came from secularized 
environments, so they underestimated how important it was what religion or denomination one belonged to. And it is precisely religion that is responsible for the creation of a powerful model of an excluding identity, providing an incredibly significant tool for demarcating and underlining social divisions in holiday and everyday praxis. What is more, religion maintained its potential for differentiation despite the grand change from the estate system to modern national and capitalistic democracy. In old European cities there were districts or streets reserved for members of a group isolated on the basis of religion. Jewish districts were the most frequently created, but there were also parts of cities designated for Armenians and Orthodox Christians. Zamość, founded and built in the late 16th century, was an interesting example. Within the walls, the city was not large, so separate districts were not formed. However, every minority group (that is, not Roman Catholic) received the right to settle, the privilege to build its own temple and keep its sacred calendar, while respecting the dominant religion (see Kowalczyk 1980). It is not so much the territory (in the case of Zamość, there are only single streets) as the law and custom that characterize belonging to a religion: law because an individual is subject to the civil law of the religion he professes, and it is obvious that the code of another religion does not concern him, custom because most behaviors, everyday practices, actions connected with important moments in life are regulated by customs that most often were at one point tied to religion. Different ways of making the sign of the cross by Orthodox Christians and Catholics, different songs sung in church by Protestants and Catholics, different rules regarding one's personal appearance - everything that is not quite formally regulated, but determines the shape of the everyday life. Religion used to influence every area of life; today it revives itself mainly in the sphere of high, festive tradition and some practices of everyday life.

Formerly, it was most often religion, next to the estate, that determined social classification, and often its influence is felt to this day. It is religion and by extension, different customs and heritage that differentiate Croats, Serbs and Bosnians. The most visible conflict in contemporary France occurs, it seems, between secular France that is nevertheless built on Gallican Catholicism, and Muslims living in the country but adhering to a different value system. In Bulgaria religion and the whole meaning of differences in cultural practices separates Orthodox autochthons from Muslim Pomaks; depending on the political context, the latter are treated either as members of the same nation, but of different faith, or as foreigners, sometimes even exemplary enemies of the national community. Most of the time, they have been disliked and misunderstood. In some places it is still religion that determines an individual's place and role in the social 
sphere, and interestingly, this is not just the case of places like the Balkans, but also of great modern cities such as Paris, London and Vienna.

Religious divisions have always shown a tendency to set up clear and sharp borders. Like national identity, they are governed by the principle of excluded middle. One cannot be a bit a Muslim and a bit a Catholic, especially that belonging to a religious community is governed by a number of rituals that confirm and constantly strengthen the social aspect of religion. The "others" are almost always seen as a homogenous community, uniform and entirely different or hostile, in fact, since its existence automatically throws doubt on the values held by the members of a different religious group. The image of Islam in European media, which seem to forget about the internal variety of the religion, is a good example. The dominant representation is the one of the increasingly influential conservative Islam of the Saudi kind, while other strains receive little attention, which is harmful to the understanding of the cultural situation of different Muslim communities. Take the case of Bosnia and Herzegovina; the influence of Wahhabi Islam is noticeable, but the local Islam has worked out different customs and practices founded on its own tradition of a Christian-Muslim borderland. Yet, social categorization more and more often refers to the stereotype of a Muslim in this state as well, escalating the misunderstanding, or rather the enmity, between members of different nations and faiths. One may add that very often, though not as a rule, religion becomes an element forming a national identity as an aspect contrasting with the "other." Bosnia, Bulgaria and Poland serve as telling examples of this process.

There is one other aspect that must be addressed when speaking on the issue of the unambiguity of the perception and description of cultures. As I write the introduction to the topic of transculturality, I try to emphasize the problem of perception, of cultural concepts and of the language used to describe cultural reality, without attempting to judge actual differences between cultures caused by differences in influences (historical, political, religious, etc.). Work on the difference between the essences of cultural phenomena falls under the domain of religious and genetic studies. Of primary importance in the sphere of cultural communication are connotations, signs and their interpretations, which are subject to changing readings depending on the context, cultural skills and purposes of those participating in the process of communication. Public discourse, and especially media discourse, employs stereotypes most of the time. The term should be understood as ready interpretations, simplified mechanisms of understanding certain categories or phenomena, which allow one to understand a situation and analyze data quickly. One can hardly expect 
every participant in an exchange of information to analyze the entire context of every event, seeing as it would delay decision making. However, this model (simplified in this account) strengthens the solidification and proliferation of stereotypes, which usually refer to the differences between "us" and "them," sharpening the contrasts that help to interpret signs rapidly. The negative consequences for the account of social reality are grave. As can easily be expected, interpretations of social phenomena are impoverished and shallow; nuances have to be replaced with clear-cut traits that reinforce the stereotype. Thus, for instance, when writing about the situation in Bosnia and Bosnian-Serbian relations, it is easier to use the ready-made label of a Muslim, which is already prevalent in the media, than to try to investigate the peculiar character of local Islam. Stereotypes, cultural clichés and ready-made phrases taken from political discourse simplify the ideas of the "other," rendering the cultural dialogue shallow and reinforcing the ready-made, often false meanings. Moreover, the characteristic trait of these elements of communication is that they bring out the differences on the basis of religion, nation and culture.

One last category requires a commentary. "Cultures" referred to in the plural, which connote the greatly overused picture of "multiculturality," are understood popularly, as well as by anthropologists, as closed and rather well described wholes. " "Cultures" differ, of course, but ethnological descriptions often solidify the differences, regarding them as unchanging defining traits of a given community. Furthermore, it is hard to determine to what extent the description of a culture reflects the reality, to what extent culture "is" a description, a text created on the basis of various data (Geerz 2000). It is obvious then that a description which emphasizes the differences contributes to making them more prominent and to imposing the view that they are the best reflection of social reality. According to Ulf Hannerz, the way ethnological studies are conducted paradoxically helps to strengthen the sense that cultures are very different from each other and that they have a rather stable set of traits that allow one to determine whether given phenomena belong to a given culture. While Levi-Strauss was creating a concept of culture as a universal sphere of human existence in which individual communities realized some of the universally present potentialities, poststructuralism established a paradigm of difference, thus of cultural difference as well. Invoking cultural differences has become a universal explanation that does not require confirmation, as if it referred to something obvious in itself. The absolutisation of difference, however, leads to the situation described at the beginning of the paper: communities

This paragraph refers mainly to the theoretical propositions of Ulf Hannerz (Hannerz 2007). 
are forced into a stereotype which requires them to cultivate differences in order to defend cultural identity against influence.

There is not enough space to discuss the political aspect of this turn to absolutizing cultural identity. Yet, it has to be noted that the place of the debate about social conflict, class interests and the fight for capital (economic and cultural) within a single society has been taken up by a discussion about cultural identity. The matter of defending national identity was at the center of the discussion over Poland's or Croatia's entry to the European Union, and most of the fears, at least the ones expressed by public media, regarded that issue. In a similar vein, only to a greater extent, the breakdown of Yugoslavia and the war that accompanied it were explained by issues of a conflict between cultures. According to many analyses, differences between Croatian and Serbian culture, despite a common language, were supposedly the fundamental reason, the second being the differences between Serbs and Albanians. Little attention is paid to the interests of political elites, groups of people gathered around party leaders and local chiefs, while cultural narrations are absolutized. The picture can be misleading, and the example above is meant to show the high degree to which the notion of difference among cultures is present in today's discourse and to what extent it can supplant meanings connected with other narrations. It is no trivial matter because it will allow one to understand the possible consequences of the category of transculturality.

Transculturality refers to this traditional understanding of culture as self-contained, concentrated around its own center and producing clear borders. "Trans" signifies the act of crossing; it signifies overcoming such borders. It looks at phenomena, people, and notions that are not limited to one communicational environment, but are characterized by being present in multiple locations. Or rather-they cannot be fully ascribed to one "culture," because they exhibit, traits of both (or more) cultures. I do not mean, however, planned actions the purpose of which is to cross borders, as in the case of international projects. A good example is the life of Turar Ryskulov, which Xavier Hallez describes in this volume. It is the case of an individual whose path of life crosses several environments and cultural spheres as a result of a nexus of political and social circumstances. In some way, it fits also into the new, projected Soviet identity. It is impossible to assign Ryskulov entirely to one culture, unless one takes a macro unit, Soviet Central Asia, for instance, as the level of cultural description. The categories of "Uzbek," "Kazakh" or "Russian" are only partially applicable, and it is especially significant as Ryskulov can be considered an emblematic

This reflection was stimulated largely by the idea proposed by Wolfgang Welsch (Welsch 1999). 
figure for certain environments and times. Another case, analyzed in this issue by Karolina Bielenin-Lenczowska, are the stories of the second generation of Macedonian emigrants in Italy. They are often people with "trans" life stories; it is not a matter of simple crossing of borders, living a bit in one environment and a bit in another. The point is that their sense of belonging is of a mixed, ambiguous character, and their identity is blurred. It is a question of practices that they draw from two or more sources, creating a peculiar amalgam characteristic of living "in between." Transculturality, just like multiple biographies, means both partial belonging and dual belonging, which is very well illustrated by the case of Macedonian emigrants: they have in a way, varied roots, which means they bear unique, hybrid fruit.

The deconstruction of the term "culture" along with its totalizing use is proposed by other texts as well. It is worth considering whether in speaking about culture we do not, in fact, mean a certain complex entity, which exists on several levels and which cannot be described as a static, stable and clearly defined whole. Marta Petryk's article about the problematic terms referring to a certain ethnic group inhabiting Norway justifies the conclusion. Through language, Petryk shows not only variation of names, but also variation of identity and finally, culture. Kvens are a group "in itself," but also "in between" (the Norwegian and Finnish areas), a group that is diverse, but which also creates certain common models of behavior and of ideas. Perhaps it is better to think about it not as a tight, homogenous identity, but as a certain collection of varied life stories that intertwine, but also often go in different directions? On the micro level, one notices that which is invisible from a general, national for instance, perspective. This theme, as well as the issue of Macedonian emigrants or Kven interlocutors of Marta Petryk, leads one towards studies of individual life stories enmeshed in broader political and cultural contexts. A view from the perspective of the grass roots is anthropology's greatest contribution to the contemporary paradigm of social sciences, and the conception of transculturality owes the most to this particular approach.

An ethnic label is necessary, of course, but it must be understood as a functional tool which facilitates the description of reality, but does not exhaust it. The cases of Romani engagement with cultures they come in contact with seem especially instructive. But more than that, Joanna Talewicz-Kwiatkowska's article makes us aware of the internal diversity of the Romani culture in Poland - or maybe of the difference between cultures (in the plural?). Where we used to see a uniform ethnic group there now appears a mosaic and one that changes over time, on top of that. The question of identity, and also of the usefulness of the verbal label, returns 
in Maria Kuglerova's article, in which she reflects on the fate of the Romani under the circumstances of a double, Russian and Soviet, context.

One can hardly overestimate the theoretical value and its analytical implications of Ewa Eukaszyk's article devoted to the cultural dilemma connected with the role of an intellectual active in two worlds. Though perhaps it would be more accurate to say that, as with Farish Noor, it is a case of a person coming from two civilizational traditions, if we consider origin to denote not only first socialization and genetics, but also intellectual formation. It is also a question of responsibility towards oneself and fellow members of the communities to which a given individual belongs. The problem outlined by the author adds a significant context to former discussions, one that is especially important to today's world. After all, Europe not only extends its influence, which is peculiarly revealed by Xavier Hallez's text, but has to conceptualize it on its own territory, as in the case of the hero of Ewa Eukaszyk's text. Meanwhile, some texts reminds us that we do not need to understand culture as an entity based on an ethnic code, which leads to a false image of national homogeneity opposed to an ethnic "other." A difference of culture can occur within a nation, creating different communicational groups that view each other as foreign. And it is precisely studies centering around the category of masculinity as the factor which causes the most important cultural difference that carry the potential to discover such fractures, changes which create, in fact, new "cultures," forcing individuals to live in suspension, in a "trans" social space.

The term "transcultural experience" reflects most accurately the idea of the main theme. It does not suggest any rigid cultural entity, as in the case of the term "transculturality," but points towards the experienced and contextual aspect of cultural reality. Transcultural experience can appear on different levels of the description of culture and in various places. It is not limited to simple contact between two "cultures." By speaking of experiencing transculturality, I wish to take the stance that culture should be viewed as a kind of continuum, where one can talk about the extent and intensity of influence, but not rigid borders; where various factors must be taken into account, if the situation is to be analyzed correctly, and where one should not trust unambiguous national or religious narrations, but open oneself up to viewing the world from the perspective of micro phenomena and individual actions. This is the reason behind adding the phrase "varied life stories" as a specification of the main topic. Though not all authors have chosen this approach, it seems that, and the figure of Ryskulov and the Macedonians in Italy confirm this claim, it is precisely a life story read as a cultural text that unveils various dimensions of participating in a culture or cultures - most fully. An individual makes choices, but is also induced to 
make them; some actions are performed consciously, and others result from activated potentialities of a habitus. The description proposed here is never limited to a psychological view, but sees man in a social dimension, thus the studies of varied life stories will take the socioanalytic approach. We hope that the texts being offered to the reader demonstrate the fruitfulness of this approach and induce some to take up further studies in this vein.

In the section entitled "Materials," we present various texts that constitute an interesting extension of the research perspective of the main part. Mario Hibert presents the problem of access to information, circulation of intellectual goods, as well as the control and supervision of gaining knowledge. In other words, the text makes one think about the basis of contemporary participation in culture, which includes, of course, the issue of transcultural experience. The next two articles are about post-socialist cinema - in Bosnia and in Russia. It is the cinema that turns out to be a medium surprisingly blind to changes, as in the Russian case, or becomes a venue for manipulation or for definition of desirable meanings, as is demonstrated by the Bosnian example. At the end of the issue we present two translations: the first is a translation of excerpts from the Serbian Story of Alexander, which completes the discussion on the Greek version of the romance and its relation to the Serbian prototype that was begun in the last issue. The second refers directly to the problem of transculturality, as it is Jorg Schult's translation of four sonnets by Czernyshevsky. Here a Jewish poet and writer from the borderland between Ukraine and Poland becomes the hero of a cultural story, which unveils various themes and diverse voices that constitute a unique life story.

We hope that the material being presented here will find readers ready to devote some time to the title theme and the matters discussed in each article. We believe the problem of transcultural experience is highly significant, and it certainly requires a more in-depth study. We would like this issue of Colloquia Humanistica to initiate the discussion.

\section{References}

Anderson Benedict (1997). Wspólnoty wyobrażone: Rozważania o źródłach i rozprzestrzenianiu się nacjonalizmu. Transl. S. Amsterdamski. Kraków: Znak.

Chomątkowska Beata (2012). Stacja Muranów. Wołowiec: Wydawnictwo Czarne.

Dąbrowska-Partyka Maria (2008). Literatura pogranicza, pogranicza literatury. Kraków: WUJ.

Edensor Tim (2004). Tożsamość narodowa, kultura popularna i życie codzienne. Transl. A. Sadza. Kraków: WUJ.

Falski Maciej (2010). "Miasto realne, miasto cyfrowe: podwójny żywot Trebinja”. In: 
Goszczyńska Joanna i Szwat-Gyłybowa Grażyna (eds.), Znaczące przestrzenie Słowiańszczyzny. Warszawa: 87-111.

Gavazzi Milovan (1928). “Kulturna analiza etnografije Hrvata”. Narodna starina, 7 (16). Geerz Clifford (2000). Dzieło i życie: antropolog jako autor. Transl. E. Dżurak i S. Sikora. Warszawa: KR.

Hannerz Ulf (2007). Powiązania transnarodowe. Kraków: WUJ.

Kapralski Sławomir (2012). Naród z popiołów: pamięć zagłady a tożsamość Romów. Warszawa: Scholar.

Kowalczyk Jerzy (ed.) (1980). “Zamość miasto idealne. Lublin: Wydawnictwo Lubelskie. Kwaśniewski Krzysztof (1993). “Elementy teorii regionalizmu”. In: K. Handke (ed.). Region, regionalizm. Warszawa: 75-87.

Laignel-Lavastine Alexandra (2010). Cioran, Eliade, Ionesco: O zapominaniu faszyzmu. Trzech intelektualistów rumuńskich $w$ dziejowej zawierusze. Transl. I. Kania. Kraków: Universitas.

Macura Vladimir (1995). Znamení zrodu: české národni obrození jako kulturní typ. Praha: H\&H.

Thiesse Anne-Marie (1999). La création des identités nationales. Paris: Seuil.

Weber Eugen (1976). Peasants into Frenchmen: The Modernization of Rural France, 1870-1914. Stanford University Press.

Welsch Wolfgang (1999). "Transculturality - the Puzzling Form of Cultures Today". In: M. Featherstone (ed.). Spaces of Culture: City, Nation, World. London: 194-213.

\section{Doświadczenie transkulturowe i biografie wielorakie jako temat badawczy}

Transkulturowość odnosi się do tradycyjnego pojmowania kultury jako samowystarczalnej, skoncentrowanej na sobie i wytwarzającej wyraźne granice. Przyrostek „trans” oznacza akt przekraczania tak wytyczonych granic. Kategoria transkulturowości skłania do patrzenia na zjawiska, biografie i pojęcia jako coś, co nie ogranicza się do jednego środowiska komunikacyjnego, lecz występuje bądź przejawia się w wielu miejscach i kontekstach. Można też powiedzieć, że nie można ich przypisać do jednej „kultury”, ponieważ reprezentują cechy dwóch (lub więcej) wspólnot kulturowych. Studia kulturowe często zajmują się osobami, czyje historie życia mają taki właśnie charakter "trans-graniczny” charakter. Nie chodzi przy tym jedynie o proste przejście granic, życie trochę w jednym, a trochę w drugim środowisku. Istotne jest to, że poczucie przynależności staje się niejasne lub wielorakie. Pojawia się na przykład kwestia praktyk związanych z dwoma lub więcej źródłami wzorców, co tworzy specyficzny amalgamat życia „pomiędzy”. Transkulturowość, podobnie jak biografie wie- 


\section{Maciej Falski}

lorakie, oznacza zarówno częściową, jak i zróżnicowaną identyfikację, którą świetnie ilustrują studia przypadków przedstawione w trzecim numerze „Colloquia Humanistica"; można by rzec, iż mają one różnorodne korzenie, przez co rodzą wyjątkowe, hybrydyczne owoce.

24 colloguia humanistica 